\title{
Effects of destruxin A on Rhipicephalus (Boophilus) microplus ticks (Acari: Ixodidae)
}

\author{
Efeitos da destruxina A no carrapato Rhipicephalus (Boophilus) microplus (Acari: Ixodidae)
}

Patrícia Silva Gôlo ${ }^{1}$; Isabele da Costa Angelo²; Mariana Guedes Camargoㅜ;

Wendell Marcelo de Souza Perinotto ${ }^{1}$; Vânia Rita Elias Pinheiro Bittencourt ${ }^{1 *}$

${ }^{1}$ Postgraduate Program on Veterinary Sciences, Department of Animal Parasitology, Veterinary Institute,

Federal Rural University of Rio de Janeiro - UFRRJ

${ }^{2}$ Department of Epidemiology and Public Health, Veterinary Institute, Federal Rural University of Rio de Janeiro - UFRRJ

Received February 18, 2011

Accept March 4, 2011

\begin{abstract}
This study evaluated the effects of destruxin A on Rhipicephalus (Boophilus) microplus females, since this toxin is one of the likely causes of high mortality induced by the entomopathogenic fungus Metarhizium anisopliae in arthropods. Ticks were immersed or inoculated with different concentrations of destruxin A. Despite the doses applied, there were no deaths or significant alterations in oviposition between the groups treated with destruxin $\mathrm{A}$ and the control groups. No other external effect caused by destruxin, such as tetanic paralysis, was observed in these engorged female ticks after the treatment.
\end{abstract}

Keywords: Metarhizium anisopliae, fungal metabolites, biological control.

\section{Resumo}

Este estudo avaliou os efeitos da destruxina A em fêmeas de Rhipicephalus (Boophilus) microplus, uma vez que essa toxina é uma das prováveis causas da alta mortalidade induzida pelo fungo entomopatogênico Metarhizium anisopliae em artrópodes. Os carrapatos foram imersos ou inoculados com diferentes concentraçóes de destruxina A. Apesar das doses aplicadas, náo houve mortes ou alteraçóes significativas de postura entre os grupos tratados com destruxinas A e os grupos controle. Nenhum outro efeito externo provocado pela destruxina A, tal como paralisia tetânica, foi observado nas fêmeas ingurgitadas de carrapato após o tratamento.

Palavras-chave: Metarhizium anisopliae, metabólitos fúngicos, controle biológico.

\section{Introduction}

The cattle tick Rhipicephalus (Boophilus) microplus causes significant economic losses to cattle farmers due to reduced milk and meat production, slower growth of infested animals and disease transmission. In Brazil, these economic losses have been estimated as two billion dollars a year (GRISI et al., 2002). Tick control is generally based on the use of chemical acaricides, but their continual application and improper use have many negative side effects, including the development of chemical resistance in tick populations and food and environmental contamination. Biological control is an alternative to the use of chemical acaricides. Of all the entomopathogenic fungal genera and species that have been tested, Metarbizium anisopliae is among the most often investigated, because of its potential for controlling tick species worldwide (FERNANDES; BITTENCOURT, 2008).

\footnotetext{
${ }^{*}$ Corresponding author: Vânia Rita Elias Pinheiro Bittencourt Departamento de Parasitologia Animal, Instituto de Veterinária, Universidade Federal Rural do Rio de Janeiro - UFRRJ,

Rod. BR 465, Km 7, CEP 23890-000, Seropédica, RJ, Brasil

e-mail:vaniabit@ufrrj.br
}

The infection pathway of $M$. anisopliae consists of attachment of the spore to the cuticle, germination and formation of appressoria, thereby leading to penetration through the cuticle. After overcoming the host's response and immune defense reactions, this fungus spreads within the host by forming hyphal bodies, outgrowing the dead host and producing new conidia (ZIMMERMANN, 2007). While spreading within the host, the fungus produces secondary metabolites, which have a toxic effect on the host. Thus, the efficiency of this fungus is due not only to its physical proliferation, but also to its chemical action. Studies on insects have shown that there is a direct relationship between $M$. anisopliae virulence and destruxin production (PAL et al., 2007). However, the mechanisms for this effectiveness against ticks are unclear.

Destruxins are toxic secondary metabolites produced by entomopathogenic fungi, including $M$. anisopliae, and are considered to have insecticidal properties. This group of cyclic depsipeptides is composed of five amino acids and one $\alpha$-hydroxy acid. Thirty-eight destruxin analogues have been reported to date (SCHRANK; 
VAINSTEIN, 2010). They differ in the R-group of the hydroxyl acid residue and appear to have overlapping but different biological effects. These effects include insecticidal, herbicidal and antiviral ones (HU; REN, 2004). However, the mechanism through which destruxin production increases fungal pathogenicity is not totally understood. Studies have reported that destruxins may be involved with insect-cuticle dissolution, immune system suppression and interference in host ion channels (causing tetanic paralysis), as well as other cell dysfunctions (DUMAS et al., 1996; VILCINSKAS et al., 1997). The target organs of these cyclic peptides in insects generally include the gut, Malpighian tubules and circulating hemocytes (DUMAS et al., 1996). The reports on insects also include different modes of action, such as contact, antifeedant and growth regulation modes. Nevertheless, there are no reports on the effects of destruxin on ticks. Moreover, clarification of the mechanisms involved in the process of tick infection by fungi is a crucial step towards developing new biological agents that can be used against these ectoparasites.

The purpose of this study was to evaluate the effects of destruxin A from $M$. anisopliae on engorged $R$. (B.) microplus females, using immersion and inoculation methods for infection. This communication reports the first comprehensive bioassays on destruxins acting against ticks.

\section{Material and Methods}

Rhipicephalus (Boophilus) microplus colony was maintained at the Federal Rural University of Rio de Janeiro, which is located in Seropédica, RJ, Brazil. To prepare the destruxin solution, one milligram of destruxin A from M. anisopliae (Sigma ; D4921 Destruxin A) was diluted in $1 \mathrm{~mL}$ of sterile distilled water. Firstly, $200 \mu \mathrm{L}$ of acetone PA $\left(\mathrm{Merck}^{\circ}\right)$ was added to optimize the dilution, followed by $500 \mu \mathrm{L}$ of sterile distilled water. After stirring, the solution was placed in a water bath for acetone evaporation. The final volume was then made up to $1 \mathrm{~mL}$ by adding $500 \mu \mathrm{L}$ of water.

For the immersion bioassays on engorged females, four groups containing six engorged female ticks of similar weights were tested: a control group and three treatment groups using destruxin $A$ at concentrations of 5, 10 or 20 parts per million (ppm). The destruxin solutions were diluted, according to each concentration, in sterile distilled water plus $0.05 \%$ Tween 80 . In the control group, the engorged females were immersed only in sterile distilled water with $0.05 \%$ Tween 80 . Each engorged female was immersed in the solution for five minutes, as described by Drummond et al. (1973), with modifications.

In the inoculation bioassay, a perforation was made at the body insertion of the fourth leg, using a hypodermic needle. The inoculum was individually calculated based on the weight of each female, as $0.075,0.15$ and $0.3 \mathrm{mg}$ of destruxin per gram of tick. Two control groups were established for the inoculation bioassay: one composed of engorged females injured by a needle, with no inoculation, and the other composed of females inoculated with $5 \mu \mathrm{L}$ of physiological solution. Each inoculated group was composed of six engorged female ticks, of similar weights. The immersion and inoculation bioassays were performed twice.
After treatment, the engorged females were placed in Petri dishes, labeled and incubated at $27 \pm 1{ }^{\circ} \mathrm{C}$ and $\mathrm{RH} \geq 80 \%$. Some biological parameters of the females were analyzed to determine the effects of destruxin $\mathrm{A}$ on $R$. (B.) microplus. The egg mass laid by each female was weighed daily and placed into individual test tubes. The eggs were then incubated at the same temperature and $\mathrm{RH}$, to allow the larvae to hatch.

The main parameters studied were: oviposition period (OP), hatching percentage (HP), egg production index (EPI) and nutrient index (NI). The EPI was calculated as the ratio between the total weight of eggs and the initial weight of engorged females and the NI was calculated as the ratio between the total weight of eggs and the subtraction between the initial and residual female weights (BENNETT, 1974). The parametric data (OP) were assessed using analysis of variance followed by the Student-Newman-Keuls test. The nonparametric data (NI, EPI and HP) were assessed using the Kruskal-Wallis test followed by Student's $t$ test. P values less than 0.05 were considered to be significant.

To detect whether there was any tetanic paralysis, the movement of the engorged females' legs was observed.

To test the viability and effectiveness of the destruxin A used in these bioassays, larvae of Galleria mellonella, a species known to be sensitive to this toxin (DUMAS et al., 1996; ROBERTS, 1966; VILCINSKAS et al., 1997), were also subjected to treatment. The larvae were provided by the Brazilian Agriculture and Livestock Research Company (Empresa Brasileira de Pesquisa Agropecuária; Embrapa), from the Embrapa Dairy Cattle Research Unit, Juiz de Fora, MG, Brazil. Twelve final-instar G. mellonella larvae (around $250 \mathrm{mg}$ ) were distributed into two groups. In the first group, $50 \mu \mathrm{L}$ of sterile distilled water was applied to the body surface of each larva and the same volume of destruxin solution, at $10 \mathrm{ppm}$, was applied to each larva in the second group. The bioassays were performed twice.

\section{Results}

There was no statistically significant difference $(P \geq 0.05)$ between the groups treated with destruxin $\mathrm{A}$ and the control groups. In other words, not only was there no contact virulence, but also the females' biological parameters that were analyzed did not differ from those of the control groups, even when the toxin was injected. The data are shown in Tables 1 and 2. The treated engorged females did not present any paralysis just after infection.

Galleria mellonella larvae treated with destruxin A presented immediate tetanic paralysis, while the water-treated group did not suffer any paralysis. This result indicates that the destruxin A solutions were viable.

\section{Discussion}

Although in this study the doses applied to the female ticks were above the $\mathrm{LD}_{50}$ for insects (AMIRI et al., 1999; THOMSEN; EILENBERG, 2000; SREE et al., 2008), the females also remained alive and did not show any change during the oviposition process. Similarly, Hu et al. (2009) reported there was no significant difference in oviposition shown by the whitefly Bemisia tabaci 
Table 1. Biological parameters of engorged Rhipicephalus (Boophilus) microplus females immersed in destruxin $\mathrm{A}$ and incubated at $27 \pm 1{ }^{\circ} \mathrm{C}$ and $\mathrm{RH} \geq 80 \%$.

\begin{tabular}{ccccc}
\hline Group & OP (days) & EPI (\%) & HP (\%) & NI (\%) \\
\hline control & $17.5 \pm 2.72^{\mathrm{a}}$ & $62.84 \pm 8.79^{\mathrm{a}}$ & $98.63 \pm 0.74^{\mathrm{a}}$ & $81.14 \pm 9.69^{\mathrm{a}}$ \\
$5 \mathrm{ppm}$ & $16.88 \pm 2.53^{\mathrm{a}}$ & $61.94 \pm 7.09^{\mathrm{a}}$ & $98.25 \pm 0.71^{\mathrm{a}}$ & $79.9 \pm 10.32^{\mathrm{a}}$ \\
$10 \mathrm{ppm}$ & $17.63 \pm 2.06^{\mathrm{a}}$ & $62.84 \pm 8.21^{\mathrm{a}}$ & $96.25 \pm 6.6^{\mathrm{a}}$ & $81.93 \pm 9.83^{\mathrm{a}}$ \\
$20 \mathrm{ppm}$ & $15.88 \pm 4.36^{\mathrm{a}}$ & $49.82 \pm 20.44^{\mathrm{a}}$ & $85.25 \pm 29.08^{\mathrm{a}}$ & $79.23 \pm 10.24^{\mathrm{a}}$ \\
\hline
\end{tabular}

OP: oviposition period; HP: hatching percentage; EPI: egg production index; NI: nutrient index; ppm: parts per million. The data are expressed as mean \pm standard deviation. Means followed by the same letter in the same column do not differ statistically $(\mathrm{P} \geq 0.05)$.

Table 2. Biological parameters of engorged Rhipicephalus (Boophilus) microplus females inoculated with destruxin A (mg per gram of tick) and incubated at $27 \pm 1{ }^{\circ} \mathrm{C}$ and $\mathrm{RH} \geq 80 \%$.

\begin{tabular}{crrrr}
\hline Group & OP (days) & \multicolumn{1}{c}{ EPI (\%) } & HP (\%) & NI (\%) \\
\hline IJ & $17 \pm 1.77^{\mathrm{a}}$ & $61.98 \pm 6.27^{\mathrm{a}}$ & $96.0 \pm 3.93^{\mathrm{a}}$ & $79.92 \pm 7.35^{\mathrm{a}}$ \\
INps & $16.5 \pm 2.88^{\mathrm{a}}$ & $54.84 \pm 6.82^{\mathrm{a}}$ & $96.0 \pm 3.93^{\mathrm{a}}$ & $75.28 \pm 5.32^{\mathrm{a}}$ \\
INd 0.075 & $16.25 \pm 1.28^{\mathrm{a}}$ & $59.37 \pm 8^{\mathrm{a}}$ & $96.88 \pm 1.55^{\mathrm{a}}$ & $79.22 \pm 10.33^{\mathrm{a}}$ \\
INd 0.15 & $16.13 \pm 1.81^{\mathrm{a}}$ & $57.24 \pm 10.98^{\mathrm{a}}$ & $97.25 \pm 3.45^{\mathrm{a}}$ & $77.55 \pm 11.85^{\mathrm{a}}$ \\
INd 0.3 & $16.38 \pm 1.69^{\mathrm{a}}$ & $56.91 \pm 12.21^{\mathrm{a}}$ & $98.0 \pm 1.31^{\mathrm{a}}$ & $77.86 \pm 11.81^{\mathrm{a}}$ \\
\hline
\end{tabular}

OP: oviposition period; HP: hatching percentage; EPI: egg production index; NI: nutrient index; IJ: females only injured by the needle; INd: females inoculated with destruxin; INps: females inoculated with physiological solution. The data are expressed as mean \pm standard deviation. Means followed by the same letter in the same column do not differ statistically $(\mathrm{P} \geq 0.05)$.

between a group treated with destruxins and the control group. Since the toxicity of molecules is usually attributed to the interaction between the substance and its target protein (HU et al., 2009), the results suggest that target proteins were absent from the organs or tissues relating to the tick oviposition process. Furthermore, based on these results, destruxin A production was not a determining factor for entomopathogenic fungal virulence towards $R$. (B.) microplus females, since the hosts' biological parameters did not change. This is an important observation with regard to clarifying the process of fungal infection in tick biological control.

Bioassays using other destruxin analogues are required in order to determine the real role of production of fungal secondary metabolites and their effects on ticks.

\section{Acknowledgements}

We are grateful to the Embrapa Dairy Cattle Research Unit (Embrapa Gado de Leite, Juiz de Fora, MG, Brazil), and especially to Dr. Marcia Prata and the PhD student Caio de Oliveira Monteiro, for providing the G. mellonella larvae used in this study. This research was supported by grants from the National Council for Scientific and Technological Development (Conselho Nacional de Desenvolvimento Científico e Tecnológico; $\mathrm{CNPq}$ ) and the Carlos Chagas Filho Research Support Foundation of the State of Rio de Janeiro (Fundaçáo Carlos Chagas Filho de Amparo à Pesquisa do Estado do Rio de Janeiro; FAPERJ). We also thank the Coordination Office for Advancement of University-level Personnel (Coordenação de Aperfeiçoamento de Pessoal de Nível Superior; CAPES).

\section{References}

AMIRI, B.; IBRAHIM, L.; BUTT, T. M. Antifeedant properties of destruxins and their potential use with the entomogenous fungus Metarhizium anisopliae for improved control of crucifer pests. Biocontrol Science and Technology, v. 9, n. 4, p. 487-498, 1999. http://dx.doi. org/10.1080/09583159929451

BENNETT, G. F. Oviposition of Boophilus microplus (CANESTRINI) (ACARIDA:IXODIDAE) I. Influence of tick size on egg production. Acarologia, v. 16, n. 1, p. 52-61, 1974. PMid:4463680.

DRUMMOND, R. O. et al. Boophilus annulatus and B. microplus: laboratory tests of insecticides. Journal of Economic Entomology, v. 66, n. 1, p. 130-133, 1973. PMid:4690254.

DUMAS, C. et al. Comparative study of the cytological aspects of the mode of action of destruxins and other peptidic fungal metabolites on target epithelial cells. Journal of Invertebrate Pathology, v. 67, n. 2, p. 137-146, 1996. http://dx.doi.org/10.1006/jipa.1996.0021

FERNANDES, E. K. K.; BITTENCOURT, V. R. E. P. Entomopathogenic fungi against South American tick species. Experimental and Applied Acarology, v. 46, n. 1-4, p. 71-93, 2008. PMid:18563593. http://dx.doi. org/10.1007/s10493-008-9161-y

GRISI, L. et al. Impacto econômico das principais ectoparasitoses em bovinos no Brasil. A Hora Veterinária, v. 21, n. 125 p. 8-10, 2002.

HU, Q.; REN, S. Review of destruxins of Metarhizium anisopliae Sorokin. Chinese Journal of Biological Control, v. 20, n. 4, p. 234-242, 2004.

HU, Q. et al. Toxicities of destruxins against Bemisia tabaci and its natural enemy Serangium japonicum. Toxicon, v. 53, n. 1, p. 115-121, 2009. PMid:19000916. http://dx.doi.org/10.1016/j.toxicon.2008.10.019 
PAL, S.; LEGER, R. J. S.; WU, L. P. Fungal peptide destruxin A plays a specific role in suppressing the innate immune response in Drosophila melanogaster. Journal of Biological Chemistry, v. 282, n. 12, p. 8969-8977, 2007. PMid:17227774. http://dx.doi.org/10.1074/jbc. M605927200

ROBERTS, D. W. Toxins from entomogenous fungus Metarhizium anisopliae: II. Symptoms and detection in moribund hosts. Journal of Invertebrate Pathology, v. 8, n. 2, p. 222-227, 1966. http://dx.doi. org/10.1016/0022-2011(66)90132-7

SCHRANK, A.; VAINSTEIN, M. H. Metarhizium anisopliae enzymes and toxins. Toxicon, v. 56, n. 7, p. 1267-1274, 2010. PMid:20298710. http://dx.doi.org/10.1016/j.toxicon.2010.03.008

SREE, K. S.; PADMAJA, V.; MURTHY, Y. L. N. Insecticidal activity of destruxin, a mycotoxin from Metarhizium anisopliae (Hypocreales), against Spodoptera litura (Lepidoptera: Noctuidae) larval stages. Pest
Management Science, v. 64, n. 2, p. 119-125, 2008. PMid:17935266. http://dx.doi.org/10.1002/ps.1480

THOMSEN, L.; EILENBERG, J. Time-concentration mortality of Pieris brassicae (Lepidoptera: Pieridae) and Agrotis segetum (Lepidoptera: Noctuidae) larvae from different destruxins. Environmental Entomology, v. 29, n. 5, p. 1041-1047, 2000. http://dx.doi. org/10.1603/0046-225X-29.5.1041

VILCINSKAS, A.; MATHA, V.; GÖTZ, P. Inhibition of phagocytic activity of plasmatocytes isolated from Galleria mellonella by entomogenous fungi and their secondary metabolites. Journal of Insect Physiology, v. 43, n. 5, p. 475-483, 1997. http://dx.doi.org/10.1016/ S0022-1910(96)00120-5

ZIMMERMANN, G. Review on safety of the entomopathogenic fungus Metarhizium anisopliae. Biocontrol Science and Technology, v. 17, n. 9, p. 879-920, 2007. http://dx.doi.org/10.1080/09583150701593963 